\title{
Optical characteristics of desert dust over the East Mediterranean during summer: a case study
}

\author{
D. Balis ${ }^{1}$, V. Amiridis ${ }^{1}$, S. Kazadzis ${ }^{1}$, A. Papayannis ${ }^{2}$, G. Tsaknakis ${ }^{2}$, S. Tzortzakis ${ }^{2}$, N. Kalivitis ${ }^{3}$, M. Vrekoussis ${ }^{3}$, \\ M. Kanakidou ${ }^{3}$, N. Mihalopoulos ${ }^{3}$, G. Chourdakis ${ }^{4}$, S. Nickovic ${ }^{5,}{ }^{*}$, C. Pérez $^{6}$, J. Baldasano ${ }^{6}$, and M. Drakakis ${ }^{7}$ \\ ${ }^{1}$ Laboratory of Atmospheric Physics, Aristotle University of Thessaloniki, P.O.Box 149, 54124, Thessaloniki, Greece \\ ${ }^{2}$ Laboratory of Lasers and Applications, National Technical University of Athens, 15780, Athens, Greece \\ ${ }^{3}$ Environmental Chemical Processes Laboratory, Department of Chemistry, University of Crete, P.O. Box 1470, 71409, \\ Heraklion, Greece \\ ${ }^{4}$ Raymetrics SA , 5, Kanari Str., Glyka Nera, Attiki, 153 54, Athens, Greece \\ ${ }^{5}$ Euro-Mediterranean Centre on Insular Coastal Dynamics (ICoD), University of Malta, Malta \\ ${ }^{6}$ Barcelona Supercomputing Center-Centro Nacional de Supercomputación (BSC-CNS), Earth Sciences Division, Edificio \\ Nexus II. C/ Jordi Girona, 29, 08034 Barcelona, Spain \\ ${ }^{7}$ FORTH-Crete, Foundation for Research and Technology Hellas, Heraklion, Crete, Greece \\ *now at: World Meteorological Organization, Geneva, Switzerland
}

Received: 31 August 2005 - Revised: 10 February 2006 - Accepted: 28 February 2006 - Published: 19 May 2006

\begin{abstract}
High aerosol optical depth (AOD) values, larger than 0.6, are systematically observed in the Ultraviolet (UV) region both by sunphotometers and lidar systems over Greece during summertime. To study in more detail the characteristics and the origin of these high AOD values, a campaign took place in Greece in the frame of the PHOENICS (Particles of Human Origin Extinguishing Natural solar radiation In Climate Systems) and EARLINET (European Aerosol Lidar Network) projects during August-September of 2003, which included simultaneous sunphotometric and lidar measurements at three sites covering the north-south axis of Greece: Thessaloniki, Athens and Finokalia, Crete. Several events with high AOD values have been observed over the measuring sites during the campaign period, many of them corresponding to Saharan dust. In this paper we focused on the event of 30 and 31 August 2003, when a dust layer in the height range of $2000-5000 \mathrm{~m}$, progressively affected all three stations. This layer showed a complex behavior concerning its spatial evolution and allowed us to study the changes in the optical properties of the desert dust particles along their transport due to aging and mixing with other types of aerosol. The extinction-to-backscatter ratio determined on the 30 August 2003 at Thessaloniki was approximately $50 \mathrm{sr}$, characteristic for rather spherical mineral particles, and the measured color index of 0.4 was within the typical range of values for desert dust. Mixing of the desert dust with other sources of aerosols resulted the next day in over-
\end{abstract}

Correspondence to: D. Balis

(balis@auth.gr) all smaller and less absorbing population of particles with a lidar ratio of $20 \mathrm{sr}$. Mixing of polluted air-masses originating from Northern Greece and Crete and Saharan dust result in very high aerosol backscatter values reaching $7 \mathrm{Mm}^{-1} \mathrm{sr}^{-1}$ over Finokalia. The Saharan dust observed over Athens followed a different spatial evolution and was not mixed with the boundary layer aerosols mainly originating from local pollution.

Keywords. Atmospheric composition and structure (Aerosols and particles; Pollution -urban and regional; Instruments and techniques)

\section{Introduction}

Atmospheric particles and particularly mineral dust particles, influence the Earth's radiation balance and climate mainly in two ways: (a) by reflecting and absorbing, both incoming and outgoing radiation (Houghton et al., 2001), depending on their chemical composition, size and state of mixing, a phenomenon termed as "direct aerosol effect", and (b) by acting as cloud condensation nuclei (CCN) and thereby determining the concentration of the initial droplets, albedo, precipitation formation and lifetime of clouds (e.g. Penner et al., 1994; Krüger and Graß1, 2002), a phenomenon termed as "indirect aerosol effect". These two impacts are very difficult to quantify and thus a large uncertainty exists with regard to the climatic role of aerosols (Houghton et al., 2001).

Published by Copernicus GmbH on behalf of the European Geosciences Union. 
Every year large quantities of dust are injected into the atmosphere over the deserts. Strong winds can blow sand from desert regions into the free troposphere, from where then it is advected over large distances (e.g. Prospero and Carlson, 1972; Prospero et al., 2002; Israelevich et al., 2003; Kubilay et al., 2005). Most of these particles are coarse (diameter $\geq 1 \mu \mathrm{m}$ ) and are thus deposited close to the source region, while the smaller particles (diameter around $0.5-1 \mu \mathrm{m}$ ) can be transported over large distances. An estimation of the emission flux of desert aerosols that is subject to long-range transport is of the order of $1500 \mathrm{Tg} / \mathrm{yr}$ (Wafers and Jaenicke, 1990).

At a global scale, the Sahara desert is the most important source of mineral aerosols. For the Saharan dust region it is estimated that every year about several hundred million tons (Prospero, 1996) up to one billion tons (D'Almeida, 1986) of desert dust are exported to the tropical North Atlantic Ocean and the Mediterranean Sea (Prospero and Carlson, 1972; Prospero et al., 1993; 2002; Prospero, 1999; Rodriguez et al., 2001). Aerosol optical properties derived from the Advanced Very High Resolution Radiometer (AVHRR) classified the Mediterranean Sea as one of the areas with the highest aerosol optical depths in the world, as reported by Husar et al. (1997), which mostly occurs during Saharan dust outbreaks.

Long-range transport of desert dust mainly takes place in the free troposphere (e.g. Prospero and Carlson, 1972; Hamonou et al., 1999; Murayama et al., 2001, Amiridis et al., 2005), where the aerosol lifetime is of the order of two weeks. As a consequence, ground-based and space-borne passive remote sensing, which provide columnar estimates of the aerosol loading cannot be used to quantify the radiative effects of mineral dust particles accurately. In addition, when visible wavelengths are used in the retrieval, thin dust plumes often remain undetected over continents because of poor knowledge of the surface reflectance characteristics, which vary with daytime and season. Dust often remains unresolved when the outbreaks are associated with cloud (cirrus) formation. In view of these shortcomings, complementary approaches to column-integrated observations are clearly required. Lidar measurements, depending on their configuration, provide detailed information for the vertical distribution of the optical properties of the aerosols.

The European Aerosol Research Lidar Network (EARLINET) (Bösenberg et al., 2001), as well as the Asian dust network (Murayama et al., 2001), provided coordinated measurements during outbreaks of desert dust. Lidar observations during the whole period of the EARLINET project (2000-2002) showed frequent transport of Saharan dust to Southern Europe and occasionally to Northern Europe. For the Eastern Mediterranean region, Papayannis et al. (2005) showed that multiple distinct dust layers of variable thickness $(200-3000 \mathrm{~m})$ were systematically observed in the altitude region between 1.5 and $6.5-\mathrm{km}$ height above sea level. For Northern Europe, Ansmann et al. (2003), described in detail a dust outbreak that almost reached Scandinavia and affected most of the EARLINET stations. This event provided a unique opportunity to study the temporal and spatial evolution of the dust optical properties as estimated by the lidar measurements. Müller et al. (2003) analysed the same event in synergy with sunphotometric data and provided detailed characterization of the geometrical and optical properties of Sahara dust over Leipzig. Based on lidar measurements during Saharan dust events in Thessaloniki, Greece, Balis et al. (2004) showed that the mixing of the pollution boundary layer and maritime aerosols obstructs the separation or even detection of dust in the lidar measurements, since the estimated optical properties are not representative for desert dust. Amiridis et al. (2005), in a statistical investigation of lidar derived aerosol optical properties over Thessaloniki, during EARLINET, showed that maximum values of aerosol optical depth (0.9) and lidar ratio (50 sr) at $355 \mathrm{~nm}$ over Thessaloniki, were seen for days associated with Saharan dust transport over the area, as well as with local pollution. During these episodes, free tropospheric particles contribute between $30-54 \%$ to the total tropospheric aerosol optical depth.

An event of long-range dust transport to the southeastern parts of Europe, observed during a short campaign organized in the frame of the EU funded project PHOENICS, is presented here. The campaign took place in the Eastern Mediterranean during summertime (although not a typical dust period) involving three stations, to study the aerosol loading characteristics over the area. During this period, a systematically high aerosol load is observed over the area when pollution, biomass burning, dust and maritime aerosols are mixed. Long-term measurements of aerosols over Crete, together with back trajectory analysis have shown that dust transport occurs in the free troposphere during summer (Mihalopoulos, unpublished data). Thus, dust physicochemical characteristics during summer can be performed by lidar. The measurements presented here provided the opportunity to study in detail the spatial and temporal evolution of the optical properties of the Saharan dust under the complex aerosol mixing conditions prevailing in the area.

The study combines the observations from three lidar instruments (at Thessaloniki, Athens and Finokalia, respectively) with aerosol optical depth (AOD) observations by a Brewer spectroradiometer and by a CIMEL sunphotometer and with 3-D trajectory analysis (HYSPLIT model).

The lidar data obtained at all three stations are discussed in terms of profiles of the particle backscatter coefficient, aerosol optical depth, lidar ratio, and Ångström exponent of backscatter (so-called "color index") calculated from spectrally resolved backscatter coefficients. Finally, the lidar data are compared with dust concentration calculated by the Dust REgional Atmospheric Modelling (DREAM) model. 
Table 1. Technical characteristics of the lidar systems.

\begin{tabular}{|c|c|c|c|}
\hline & LAP-AUTH & NTUA & RAYMETRICS \\
\hline \multicolumn{4}{|l|}{ Emitter } \\
\hline Laser & Nd:Yag Pulsed Laser & Nd:Yag Pulsed Laser & Nd:Yag Pulsed Laser \\
\hline Wavelengths & $532-355 \mathrm{~nm}$ & $532-355 \mathrm{~nm}$ & $532 \mathrm{~nm}$ \\
\hline Output energy/pulse & $250-120 \mathrm{~mJ}$ & $130-75 \mathrm{~mJ}$ & $115 \mathrm{~mJ}$ \\
\hline Repetition rate & $10 \mathrm{~Hz}$ & $10 \mathrm{~Hz}$ & $10 \mathrm{~Hz}$ \\
\hline \multicolumn{4}{|l|}{ Receiver } \\
\hline Telescope diameter & $500 \mathrm{~mm}$ & $300 \mathrm{~mm}$ & $200 \mathrm{~mm}$ \\
\hline Focal length & $5000 \mathrm{~mm}$ & $600 \mathrm{~mm}$ & $700 \mathrm{~mm}$ \\
\hline \multicolumn{4}{|l|}{ Detection Unit } \\
\hline Wavelengths & $355-532-387 \mathrm{~nm}$ & $355-532-387 \mathrm{~nm}$ & $532 \mathrm{~nm}$ \\
\hline Photomultipliers & Hamamatsu 5600P-06 & Hamamatsu R928 \& 5600P-06 & Hamamatsu R7400-P03 \\
\hline Data acquisition mode & $\begin{array}{l}12 \text { bit analog, } 250 \mathrm{MHz} \\
\text { photon counting }\end{array}$ & $\begin{array}{l}12 \text { bit analog, } 250 \mathrm{MHz} \\
\text { photon counting }\end{array}$ & $\begin{array}{l}12 \text { bit } 40 \mathrm{MHz} \text { analog, } 250 \mathrm{MHz} \\
\text { photon counting }\end{array}$ \\
\hline Reference publication: & Balis et al., 2003 & Papayannis et al., 2005 & Chourdakis et al., 2005 \\
\hline
\end{tabular}

\section{Instrumentation and methods}

\subsection{Lidar systems}

Two of the lidar systems which participated in the measuring campaign are 3-wavelength elastic backscatter-Raman lidars $(355,387$ and $532 \mathrm{~nm}$ ) and were operated by the Laboratory of Atmospheric Physics, Aristotle University of Thessaloniki (LAP-AUTH), Thessaloniki $\left(40.5^{\circ} \mathrm{N}, 22.9^{\circ} \mathrm{E}\right)$, Greece, and the National Technical University of Athens (NTUA), Athens $\left(37.9^{\circ} \mathrm{N}, 23.8^{\circ} \mathrm{E}\right)$, Greece. These two lidar stations are located at a distance of about $400 \mathrm{~km}$ and are part of the coordinated European ground-based lidar network, operated in the frame of the EARLINET Project (2000-2003) (Bösenberg, 2003). The third lidar system was installed at Finokalia $\left(35.27^{\circ} \mathrm{N}, 25.63^{\circ} \mathrm{E}\right)$ station, Crete, $80 \mathrm{~km}$ east of the city of Heraklion, about $200 \mathrm{~km}$ southeast of Athens and $600 \mathrm{~km}$ south of Thessaloniki. This system is a commercial portable single wavelength backscatter lidar operating at $532 \mathrm{~nm}$, manufactured by RAYMETRICS S.A. and was operated by the ECPL, University of Crete. Table 1 provides a summary of the main characteristics of the lidar systems used. The lidar systems at Thessaloniki and Athens have been checked for their quality within the EARLINET project. In Table 2 one can also find the results from the three intercomparisons at both the system and algorithm level which took place during EARLINET, for both lidar systems (Matthias et al., 2004; Böckmann et al., 2004; Pappalardo et al., 2004).

\subsection{BREWER spectroradiometer}

The Brewer spectroradiometer is a double monochromator consisting of two identical spectrometers equipped with holographic diffraction gratings (3600 lines/mm) operating in the first order. The operational spectral range of the instrument for the global irradiance measurements is 287.5$366.0 \mathrm{~nm}$, and its spectral resolution is $0.55 \mathrm{~nm}$ at full width at half maximum (FWHM). The absolute calibration is maintained by scanning every month a $1000-\mathrm{W}$ quartz-halogen tungsten lamp of spectral irradiance, traceable through Optronic Laboratories Inc., to the National Institute of Standards and Technology (NIST) standards. According to the provider, the uncertainty of the $1000-\mathrm{W}$ calibrated lamps is within $\pm 2.5 \%(1 \sigma)$, while an additional $\pm 2 \%$ should be expected from the transfer of the calibration to our working standards. The methodology of the AOD retrieval is described in Kazadzis et al. (2005).

\subsection{CIMEL sunphotometer}

The sunphotometric observations reported in this paper performed by a CIMEL sun-sky radiometer, which is part of the PHOTON/Aerosol Robotic Network (AERONET) Global Network. The sunphotometer is located at the roof of the Hellenic Center of Marine Research, on the north coast of Crete outside the city of Heraklion and at a distance of $20 \mathrm{~km}$ from Finokalia. The technical specifications of the instrument are given in detail by Holben et al. (1998). This automatic sun-tracking and sky-scanning radiometer makes direct sun measurements with a $1.2^{\circ}$ field-of-view, in the spectral bands of 440, 675, 870, 940 and $1020 \mathrm{~nm}$. Taking into account all the information about the instrument precision, calibration precision and data accuracy (Holben et al., 1998), the accuracy of the presented AOD measurements is estimated to be of the order of \pm 0.02 regarding the level 2 (cloud-screened and quality-assured) data (http://aeronet.gsfc.nasa.gov/) and of the order of \pm 0.03 regarding the level 1.5 (cloud-screened) 
Table 2. Lidar hardware and algorithm accuracy.

\begin{tabular}{llll}
\hline & LAP-AUTH & NTUA & Reference publication \\
\hline $\begin{array}{l}\text { System intercomparison } \\
\text { (mean backscatter profile deviation) }\end{array}$ & $6.5 \%$ @ 532nm & $6.8 \%$ @ 355nm & Matthias et al., 2004 \\
Backscatter algorithm & $5.5 \% @ 355 \mathrm{~nm}$ & $1.4 \%$ @ 355nm & Böckmann et al., 2004 \\
intercomparison & $2.9 \% @ 532 \mathrm{~nm}$ & $1.2 \%$ @ 532nm & Pappalardo et al., 2004 \\
Raman algorithm & $10 \%$ @ extinction of 355nm & $10 \%$ @ extinction of 355nm \\
intercomparison & $18 \%$ @ backscatter of 355nm & $18 \%$ backscatter of 355nm & \\
& $30 \%$ lidar ratio of 355nm & $30 \%$ lidar ratio of 355nm & \\
\hline
\end{tabular}

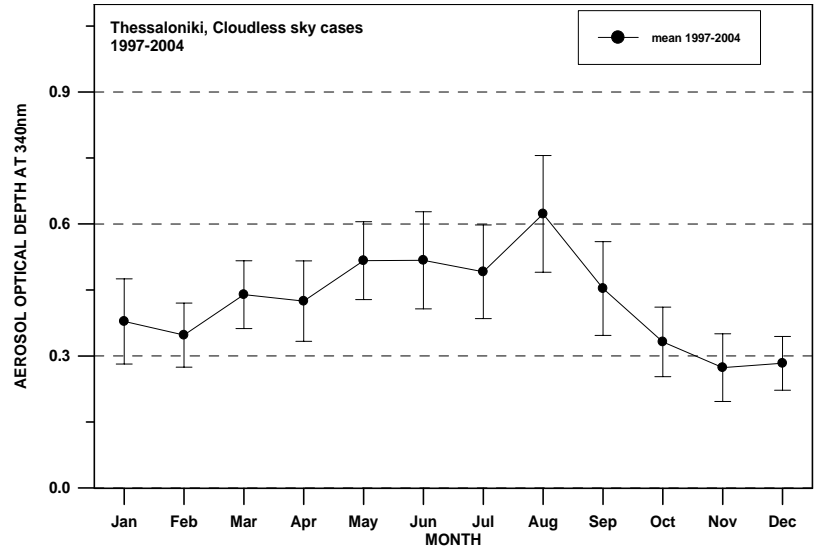

Fig. 1. Mean annual variability of the aerosol optical depth at 340nm at Thessaloniki, Greece measured by a Brewer spectroradiometer.

data. Taking the ratio between the AOD at wavelength $\lambda_{1}=440 \mathrm{~nm}$ and $\lambda_{2}=870 \mathrm{~nm}$, one can derive the Ångström exponent, $\alpha$, which provides the spectral dependence of the $\mathrm{AOD}_{\lambda}$ in the visible domain. The Ångström exponent value depends mostly on the aerosol size distribution. According to Moulin et al. (1997) small or even negative values of $a$ are found for large particles, such as sea salts or desert aerosols. In background marine conditions with a mixture of large sea-salt and small sulphate particles, Tomasi and Prodi (1982) and Hoppel et al. (1990), measured mean Ångström exponent values of 0.6 and 0.8 , respectively, for the remote marine atmosphere, and they attributed its variability ( 0.4 to $1.5)$ to the sea salt contribution. Indeed, the slightly negative Ångström exponent of large sea salt particles produced by the wind $(-0.1$, Moulin et al., 1997) tends to decrease the average value of the sea salt and sulphate mixture. Numerous works showed that where desert dust particles are present the Ångström exponent generally ranges between 0 and 0.5 over Africa (Holben et al., 1991) and over marine remote regions (Carlson et al., 1977). This parameter, in conjunction with the higher optical depths which are usually observed when desert particles are present, will thus be used to characterize the Saharan dust advected over the lidar station of Finokalia, close to where CIMEL observations are available.

\subsection{The DREAM model}

An integrating modelling system, the Dust REgional Atmospheric Modelling model (Nickovic et al., 2001), was used for the description of the dust cycle in the atmosphere. It is based on the SKIRON/Eta modelling system and the Eta/NCEP regional atmospheric model. The dust modules of the entire system incorporate the state-of-the-art parameterizations of all the major phases of the atmospheric dust life, namely production, diffusion, advection, and removal. These modules also include the effects of the particle size distribution on aerosol dispersion. The dust production mechanism is based on the viscous/turbulent mixing, shear-free convection diffusion, and soil moisture. In addition to these sophisticated mechanisms, very high resolution databases (down to $1 \mathrm{~km} \times 1 \mathrm{~km}$ ), including elevation, soil properties, and vegetation cover are utilized. DREAM has been delivering operational dust forecasts over the Mediterranean region in the last years (recently at http://www.bsc.es/projects/ earthscience/DREAM). In the operational version, for each soil texture type, fractions of clay, small silt, large silt and sand are estimated with typical particle size radii of $0.73,6.1$, 18 and $38 \mu \mathrm{m}$, respectively. After long-range transport, only the first two particle size bins are relevant for the analysis since their lifetime is larger than approx. $12 \mathrm{~h}$.

\section{Results and discussion}

\subsection{Seasonality of AOD over Thessaloniki}

Since 1997, aerosol optical depth (AOD) has been monitored by a double Brewer spectroradiometer over Thessaloniki, based on absolutely calibrated direct Sun spectra in the 295-365 nm region (Marenco et al., 1997; Kazadzis et al., 2005). Figure 1 presents the mean annual variation of the measured AOD values for the period 1997-2004 at $340 \mathrm{~nm}$. 



(a)

(b)

Fig. 2. (a) Aerosol optical depth (solid line) at $340 \mathrm{~nm}$ and Ångström exponent (330-350 nm) (dashed line) measured by a Brewer spectroradiometer at Thessaloniki, Greece, from August to September 2003. (b) Aerosol optical depth (solid line) at $440 \mathrm{~nm}$ and Ångström exponent $(440-870 \mathrm{~nm}$ ) (dashed line) measured by a CIMEL sunphotometer from the AERONET network close to Finokalia, Greece, for the period August-September 2003.

The observed values are relatively high with an overall mean value of $0.45 \pm 0.11$. Systematically, the highest values are observed during summertime and especially during August, reaching monthly mean AOD values larger than 0.60 . The corresponding mean annual variation of the Angstrom exponent (not shown here) does not show a seasonal variation, which makes the attribution of the systematically observed high aerosol loads to a distinct aerosol source difficult (e.g. Saharan dust). The origin and the evolution of these high summertime aerosol values was the main subject of the campaign which took place during August-September 2003 at three sites in Greece. The orientation of the axis (northsouth) joining the three sites coincides with common paths of Saharan dust transport over Greece (Papayannis et al., 2005), while the station of Thessaloniki is also very sensitive to trans-boundary transport of gaseous pollutants and aerosols from Central and Eastern Europe (e.g. Zerefos et al., 2000; Balis et al., 2003; Mihalopoulos et al., 1997; Lelieveld et al., 2002, Amiridis et al., 2005). In the next paragraphs the dayto-day variability of the aerosol optical depth at Thessaloniki 


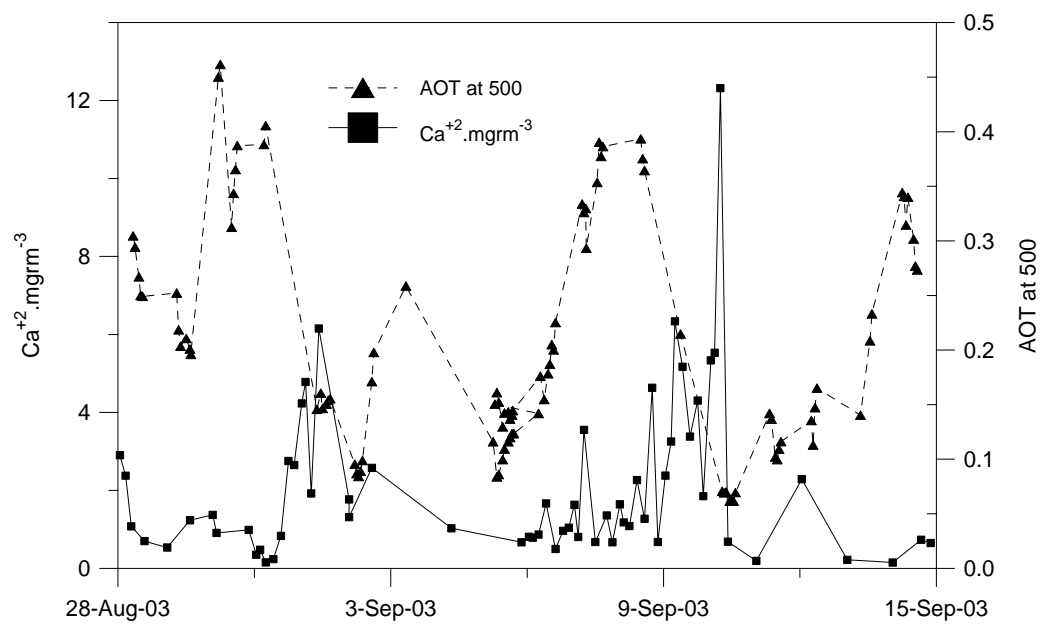

Fig. 3. Time series variation of $\mathrm{Ca}^{2+}\left(\mu \mathrm{gr} \cdot \mathrm{m}^{-3}\right)$ (black squares, left axis) and aerosol optical thickness at $500 \mathrm{~nm}$ (blue triangles, right axis) at Finokalia, Greece, during the period of 28 August to 15 September 2003.

and Crete during the campaign is presented.

3.2 Evolution of the aerosol optical depth over Thessaloniki during August-September 2003

Figure 2a shows the daily mean values of the AOD at $340 \mathrm{~nm}$ measured by the Brewer spectroradiometer over Thessaloniki during the 2003 campaign, along with the Angström exponent calculated for the 330-350-nm spectral interval. All measurements correspond to cloudless sky conditions. This figure shows very high AOD values up to 1.4 (a value that exceeds the calculated long-term $2 \sigma$ ) which were altered with short "clean" periods with AOD close to 0.2. There were four cases in 2003 (18 August, 30-31 August, 15 September, and 28-29 September) with the high AOD values being accompanied by small Ångström exponent values (less than 1). This indicates the presence of large particles. Indeed, the back-trajectory analysis suggests that during these periods the observed particles originated from the Saharan desert. From 23 to 25 August 2003 the observed AOD values close to 1 in conjunction with an Ångström exponent of 1.5, indicate the presence of smaller particles. Trajectory analysis showed that these particles in the PBL originate from local sources while particles in the free troposphere are transported from Central Europe and the Balkans. Thus, both atmospheric layers contain particles strongly influenced by continental pollution.

3.3 Evolution of the aerosol optical depth over Crete during August-September 2003

Figure $2 b$ shows the AOD at $440 \mathrm{~nm}$ as measured by a CIMEL sunphotometer from the AERONET network (FORTH station) close to Finokalia, Crete, during the same period in 2003. Five events (27 August, 31 August-
1 September, 8-10 September, 16-18 September and 21 September) have been distinguished. The Ångström exponent fell below 1.0 and even reached values as low as 0.2 , indicating the presence of large particles, while in the remaining period, it varied between 1.5 and 2 . These five events also present high AOD values larger than 0.4. Air mass trajectories indicate that Sahara desert particles were arriving at Finokalia during these periods. Similar to Thessaloniki, high AOD values associated with large Ångström exponent have also been observed on Crete (first days of August 2003) and are attributed to local and/or transported pollution from mainland Greece. However, the signature of the Saharan dust events is more discrete on the variability of AOD and Ångström exponent over Crete than over Thessaloniki. This is expected since the measuring site is closer to the Saharan desert and thus dust particles are less affected by deposition and mixing with particles from other sources. Figure 3 shows measurements of the AOD, together with the measurements of $\mathrm{Ca}^{2+}$ ions which can be used as an indicator for the presence of dust at the Earth's surface for the period 28 August 2001 to 15 September 2001. It is evident from this figure that high AOD values were always accompanied by high ion concentration with a delay of 1-2 days, providing some indication for the dry deposition processes.

\subsection{Saharan dust event during 30-31 August 2003}

The Saharan dust event which took place on 30 and $31 \mathrm{Au}-$ gust 2003 was captured by all three lidar systems and the two sunphotometers in Thessaloniki and Crete. No sunphotometric measurements were available for Athens for the reporting period. 

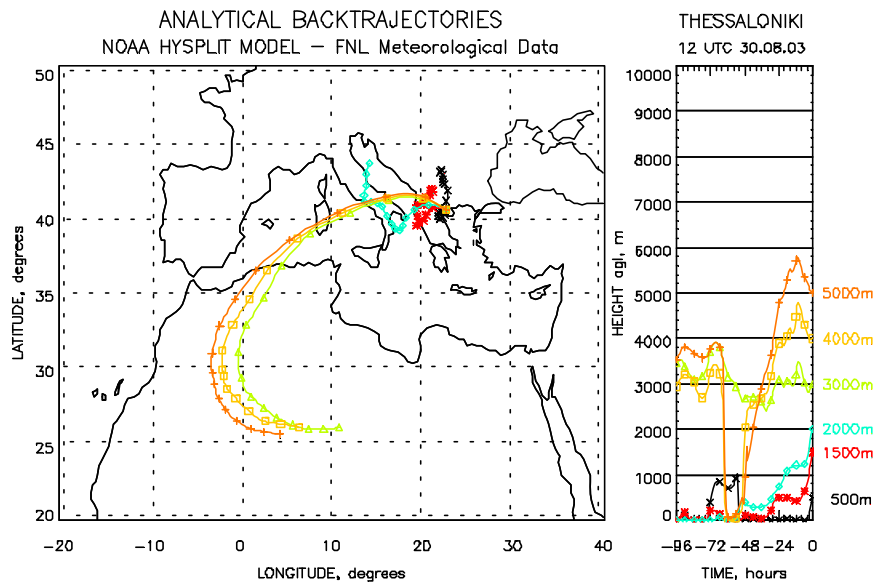

(a)
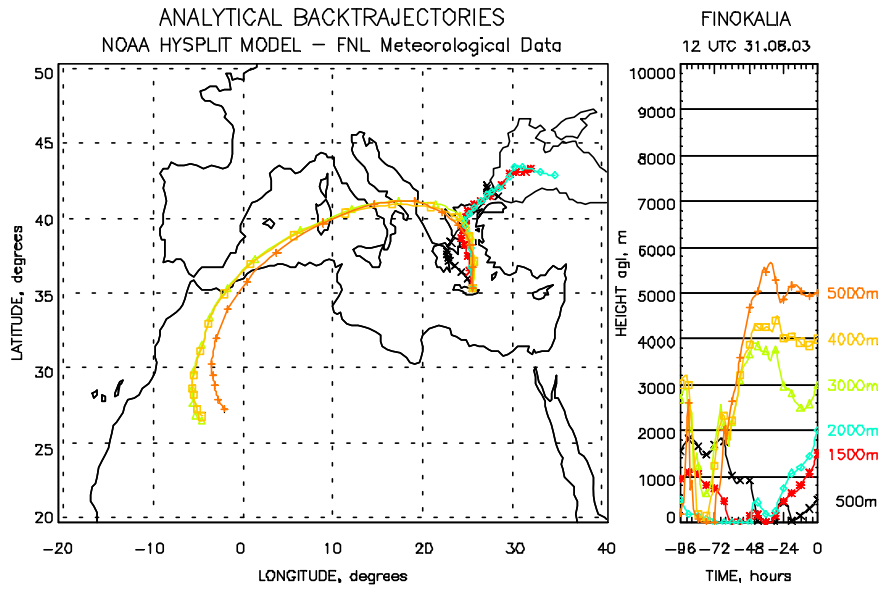

(b)
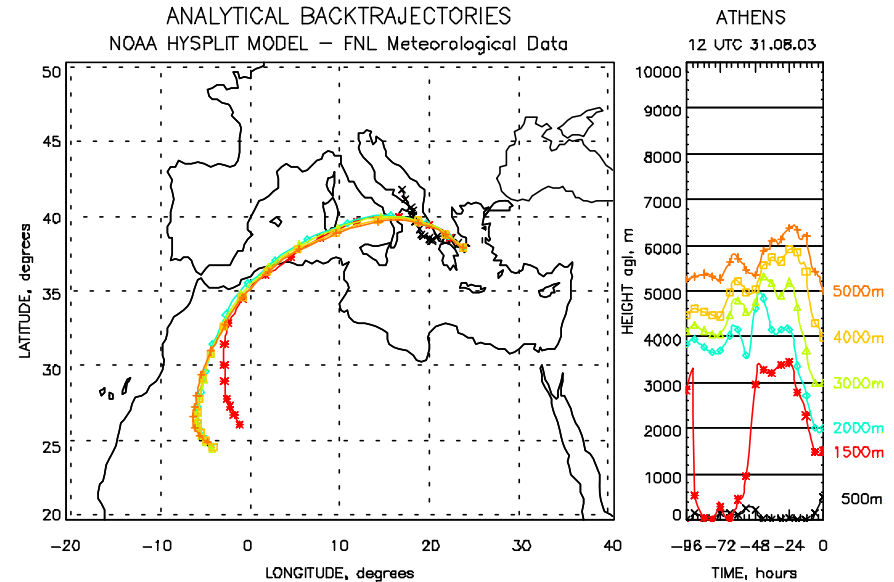

(c)

Fig. 4. Four-day back trajectories calculated with the HYSPLIT model for Thessaloniki (a), Finokalia (b) and Athens (c) for the days indicated. 


\subsubsection{Origin of sampled air masses}

Figure 4a presents the air mass four-day back-trajectories arriving at various heights over Thessaloniki at 12:00 UTC on 30 August, calculated by the HYSPLIT model (Draxler and Hess, 1998) (http://www.arl.noaa.gov/ready/hysplit4.html). The air masses that were present over Thessaloniki below $2000 \mathrm{~m}$ (i.e. in the boundary layer) were of rather local origin, since the air was lifted from the surface up to $2 \mathrm{~km}$ one day before. Between 3000 and $5000 \mathrm{~m}$, the back-trajectories indicate another aerosol layer that has been lifted to the free troposphere from the Western Saharan desert 2-4 days before 30 August. The day after, the same Saharan dust midtropospheric layer reached Finokalia, Crete, as indicated by the back-trajectories ending at Finokalia at 12:00 UTC on 31 August 2003 (Fig. 4b). In the PBL over Finokalia, the air masses originated from the NE and again seem to advect air masses from surface sources that were lifted within the PBL one day. In the free troposphere, the air masses originated again from the Western Sahara and have passed over Thessaloniki almost one day before reaching Crete. The vertical air motions at both sites, seen in Figs. 4a and b (levels $3-5 \mathrm{~km}$ ), further verify the common origin of these air masses. They are similar, shifted by one day. Based on statistics during 2000-2002 (Papayannis et al., ILRC, 2004), this air circulation pattern represents only a small percent $(5 \%)$ of the observed dust flows over the Mediterranean and occurs mostly in early spring and late summer over the Eastern Mediterranean. At the Athens lidar station, which lies along the north-south axis between Thessaloniki and Crete, dust was also observed during the same two days period. Figure $4 \mathrm{c}$ shows the origin of the air masses arriving over Athens on 31 August. These four-day back-trajectories confirm the Saharan origin of the air over Athens, although these air masses followed a different route than the ones reaching Thessaloniki and Finokalia, and also with distinct characteristics of the vertical motions at the free tropospheric levels.

\subsubsection{Evolution of the aerosol backscatter coefficients at $532 \mathrm{~nm}$}

Figure 5a presents the time cross section of the backscatter coefficient at $532 \mathrm{~nm}$ over Thessaloniki, measured by the Raman lidar in the evenings of 30 and 31 August 2003. In line with the trajectory analysis discussed earlier, there are two distinct aerosol layers evolving in the evening of 30 August. The first layer has a local origin inside the PBL and the second layer with backscatter coefficients up to $3 \mathrm{Mm}^{-1} \mathrm{sr}^{-1}$ lies between 3000 and $4000 \mathrm{~m}$. According to the backtrajectories, this second layer contains desert dust. During the evening of the second day it seems that mixing took place between these two layers, resulting in a decrease in the aerosol backscatter with height, showing, however, significant aerosol load with a backscatter coefficient around
$2 \mathrm{Mm}^{-1} \mathrm{sr}^{-1}$, up to $3-\mathrm{km}$ height. Figure $5 \mathrm{~b}$ depicts similar observations by the RAYMETRICS portable backscatter lidar at Finokalia, Crete. For the calculation of the backscatter coefficient profiles at Finokalia, we used a constant lidar ratio equal to $40 \mathrm{sr}$. The measurements started in the evening of 30 August and continued until the afternoon of 31 August 2003. In the evening of the 30 August a weak aerosol layer is present at $2 \mathrm{~km}$, which most probably corresponds to the residual layer of 30 August. An elevated aerosol layer extending from 3 to $4 \mathrm{~km}$ appears early in the morning (around 03:00 UTC) of 31 August, with backscatter coefficient values between $1-2 \mathrm{Mm}^{-1} \mathrm{sr}^{-1}, 8 \mathrm{~h}$ after the observation of a similar layer over Thessaloniki. Later in the morning of 31 August this layer shows backscatter coefficient values of the order of 3-4 $\mathrm{Mm}^{-1} \mathrm{sr}^{-1}$. Then the layer descents (also confirmed by the trajectories, see Fig. 4, level $3 \mathrm{~km}$ ) and becomes mixed with air masses originating from the boundary layer and also probably polluted air advected from mainland Greece and Turkey (see Fig. 4b, layers below $2 \mathrm{~km}$ ). This mixing results in high aerosol loading at $2-3 \mathrm{~km}$, reaching backscatter values close to $7 \mathrm{Mm}^{-1} \mathrm{sr}^{-1}$. In the afternoon most of this aerosol fades into the mixing layer (below $1 \mathrm{~km}$ ) and becomes further mixed with local air-masses, however the significant aerosol load remains in the free troposphere with backscatter coefficient values close to $2 \mathrm{Mm}^{-1} \mathrm{sr}^{-1}$. Figure $5 \mathrm{c}$ presents the aerosol backscatter coefficient measured over Athens during the same two days. The observed variability over Athens is much different than the one observed over Thessaloniki and Finokalia. During both days high backscatter coefficient values up to $7 \mathrm{Mm}^{-1} \mathrm{sr}^{-1}$ were observed below $\mathrm{km}$, associated with local pollution from the greater Athens area. An elevated layer at $4 \mathrm{~km}$ is present over Athens after 16:00 UTC on 30 August, which was not observed over Thessaloniki. The next day around noon a layer of moderate aerosol loading $\left(3 \mathrm{Mm}^{-1} \mathrm{sr}^{-1}\right)$ is present at $5 \mathrm{~km}$ and penetrates down to the PBL in the afternoon. Both elevated layers, according to the trajectories (Fig. 4c) originate from the Western Sahara, following, however, different paths, relative to the ones observed over Thessaloniki and Finokalia.

Figure 6 presents the analysis of the cloud cover (upper panel), dust load (middle panel) and dust dry deposition (lower pannel) for these two days as estimated by the DREAM model. It is obvious from the cloud cover analysis that both days were characterized by cloudless sky conditions over entire Greece, which facilitated continuous lidar and sunphotometric measurements which were not biased by the presence of clouds. The middle panel of Fig. 6 presents the dust load as estimated by the model, for 30 (left) and 31 (right) August 2003. On 30 August 2003 the dust originated from the Western Sahara, passed over Southern Italy and reached Northern Greece following an anti-cyclonic motion. On 31 August 2003 this anticyclonic system was slightly tilted to the east, resulting in a significant dust load over the entire Greece. This tilt explains the different characteristics 
Aerosol backscatter coefficient at $532 \mathrm{~nm}\left(\mathrm{~km}^{-1} \mathrm{sr}^{-1}\right)$, Thessaloniki

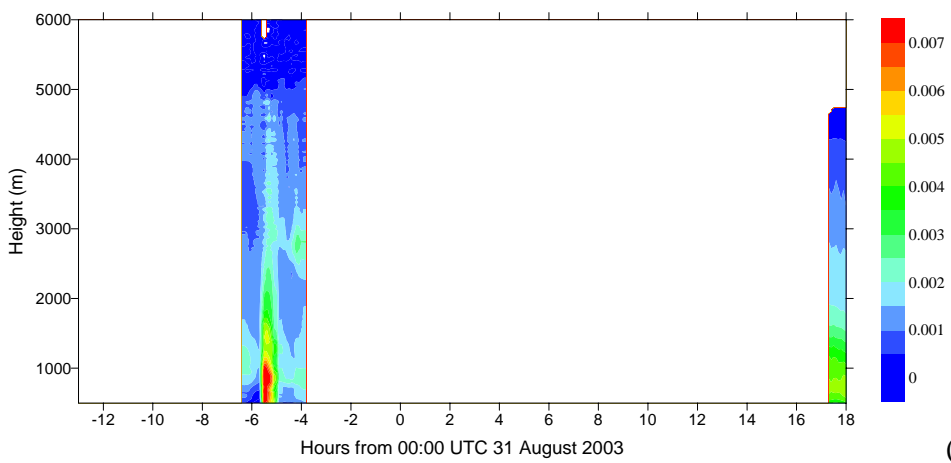

(a)

Aerosol backscatter coefficient at $532 \mathrm{~nm}\left(\mathrm{~km}^{-1} \mathrm{sr}^{-1}\right)$, Finokalia, Crete

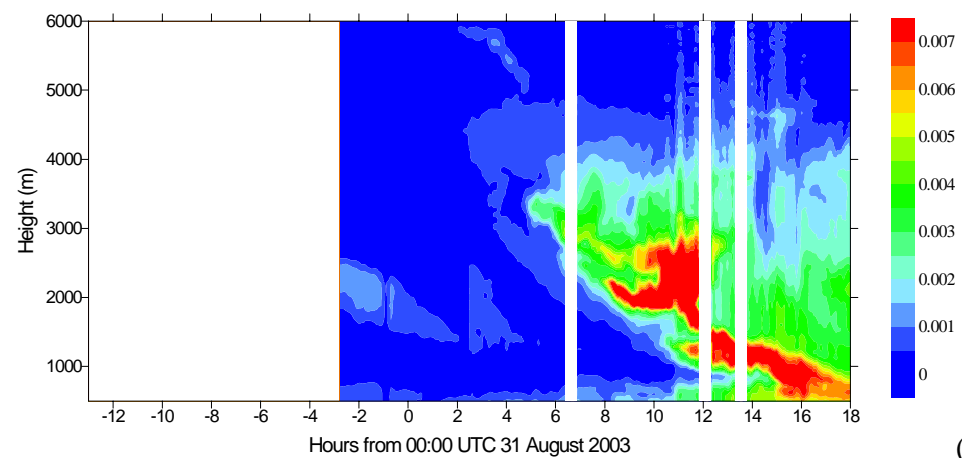

(b)

Aerosol backscatter coefficient at $532 \mathrm{~nm}\left(\mathrm{~km}^{-1} \mathrm{sr}^{-1}\right)$, Athens

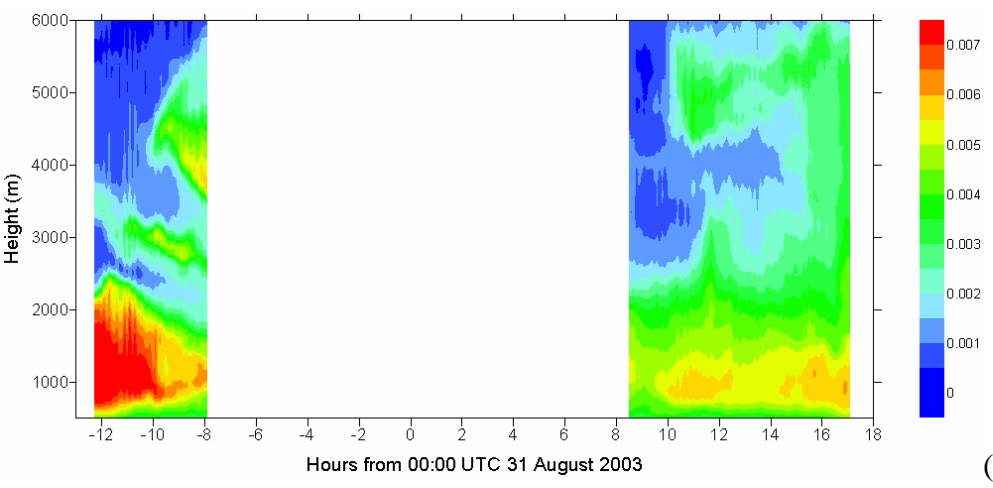

(c)

Fig. 5. Time-height cross section of the aerosol backscatter coefficient at $532 \mathrm{~nm}\left(\mathrm{in} \mathrm{km}^{-1} \mathrm{sr}^{-1}\right.$ ) at Thessaloniki (a), Finokalia (b) and Athens (c) measured at during 30 and 31 August 2003.

of the spatial evolution of the event as observed at Thessaloniki, Finokalia and Athens.

Next we present in more detail some optical characteristics of the observed dust layers over Thessaloniki and Athens where Raman lidar measurements were available. Figure 7 shows the vertical profiles of the backscatter coefficients at 355 and $532 \mathrm{~nm}$, the vertical profile of the dust concentration simulated by the DREAM model and the vertical profile of the lidar ratio and the color index measured over Thessa- loniki on 30 and 31 August 2003 around 17:00 UTC. The calibration height for the calculation of the backscatter coefficient was set in a height region with negligible particle load considered as an aerosol-free region. The uncertainties of the color index in terms of calibration errors can be regarded as negligible when they are compared to the uncertainties caused by a misestimation of the lidar ratio at $532 \mathrm{~nm}$, where no Raman channel is available. For the retrieval of the color index we used at both wavelengths the 

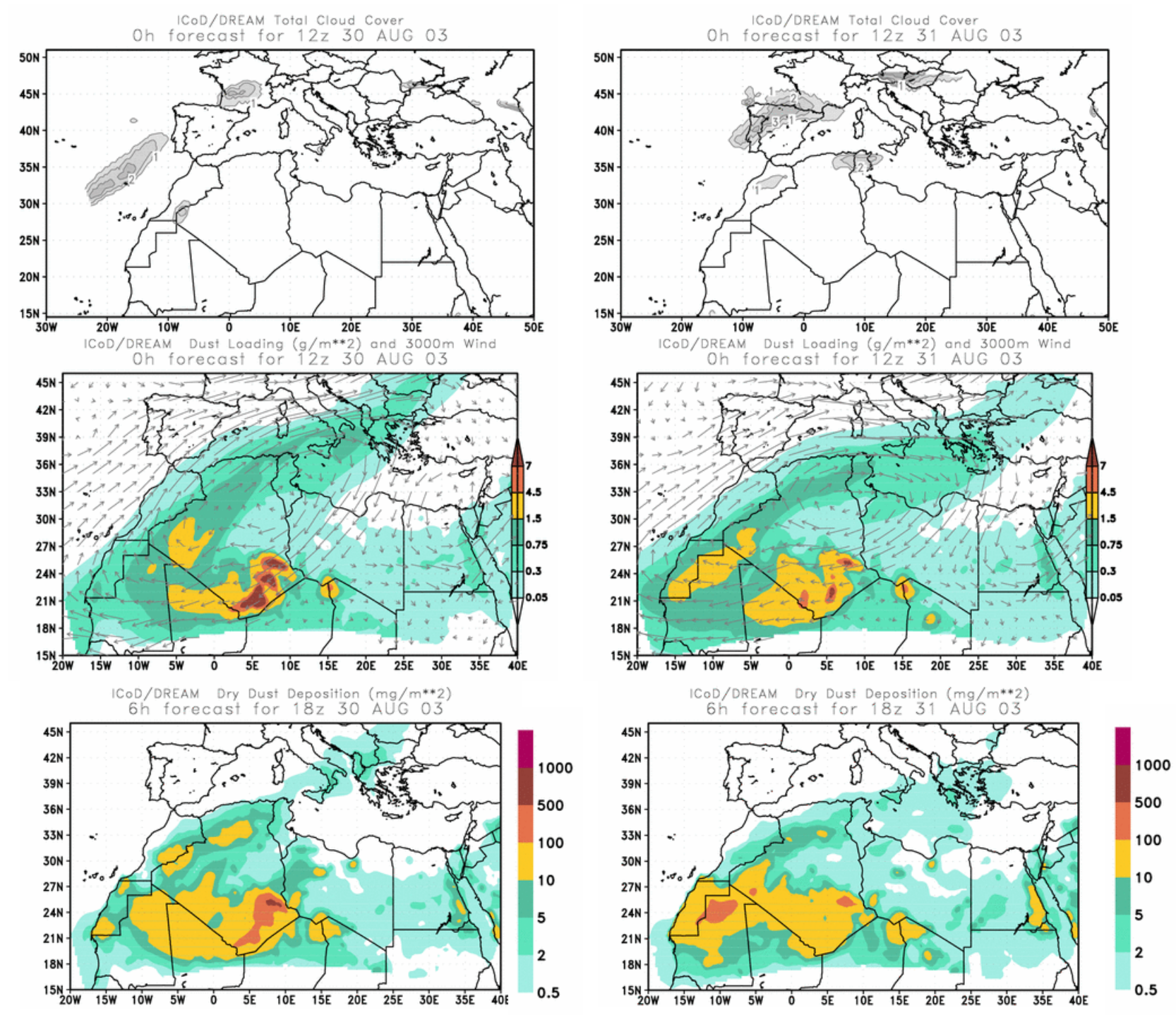

Fig. 6. Analysis of cloud cover and dust load (in $\mathrm{g} / \mathrm{m}^{2}$ ) for 30 and 31 August 2003 estimated by the DREAM model.

measured lidar ratio at $355 \mathrm{~nm}$. An uncertainty of $10 \mathrm{sr}$ in the retrieval of the backscatter coefficient at $532 \mathrm{~nm}$ can introduce a difference of 0.25 in the color index under moderate aerosol loading. The weak dependence of the backscatter coefficient on the wavelength observed on 30 August indicates the presence of large particles and provides further evidence of Saharan dust aerosols. There is a good agreement on the thickness and location of the dust layer between the model simulation and the lidar measurements. The observed backscatter coefficient values on 31 August are larger than the days before and the shape of the profile indicates wellmixed aerosols up to $4500 \mathrm{~m}$. The dust simulation, however, shows a layer at about $3000 \mathrm{~m}$. In addition, the estimated concentrations are 3 times less than the day before, which, in conjunction with the dry deposition forecast from the DREAM model (lower panel of Fig. 6), indicates the possible removal of dust from the air-masses during this one-day period. On 30 August, the observed lidar ratios show a distinct layer above $3000 \mathrm{~m}$ with a mean value close to $50 \mathrm{sr}$, which coincides with small color index values below 0.5 . Both values are typical for desert dust (Mattis et al., 2002; Ansmann et al., 2003; Balis et al., 2004). Below this layer, the color index and the lidar ratio values are larger, indicating the existence of a different type of aerosols and the absence of significant mixing processes in the vertical, also verified by the trajectories shown in Fig. 4. On 31 August the observed lidar ratio is rather constant with height. Although the air-masses contain dust, the lidar ratio and the color index profiles show mean values of less than $20 \mathrm{sr}$ and larger than 1 , respectively, which are not representative for mineral 


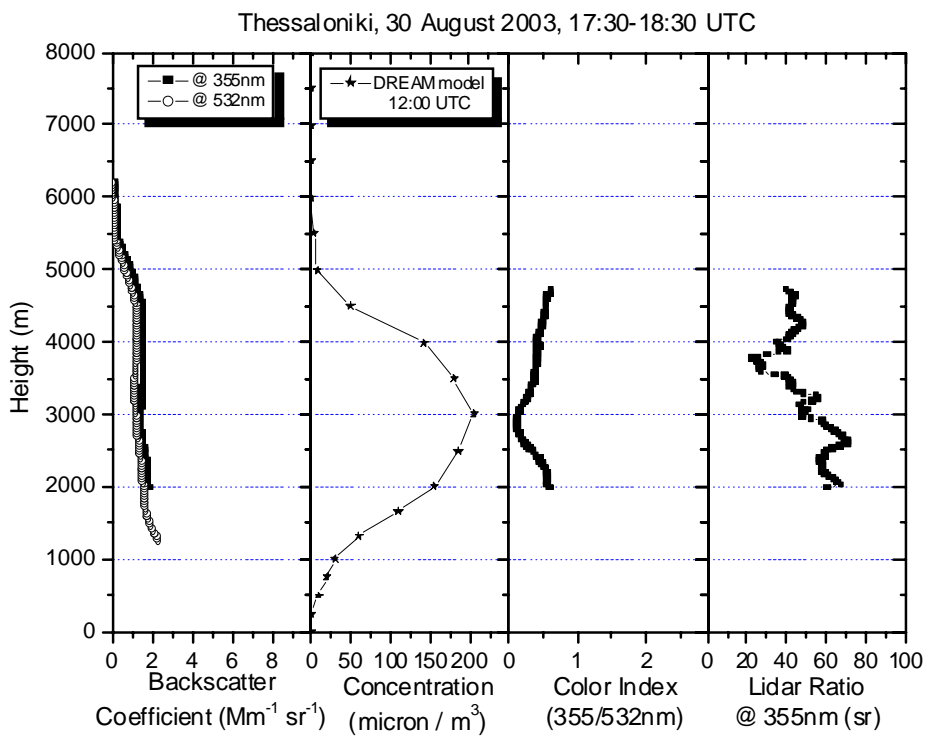

(a)

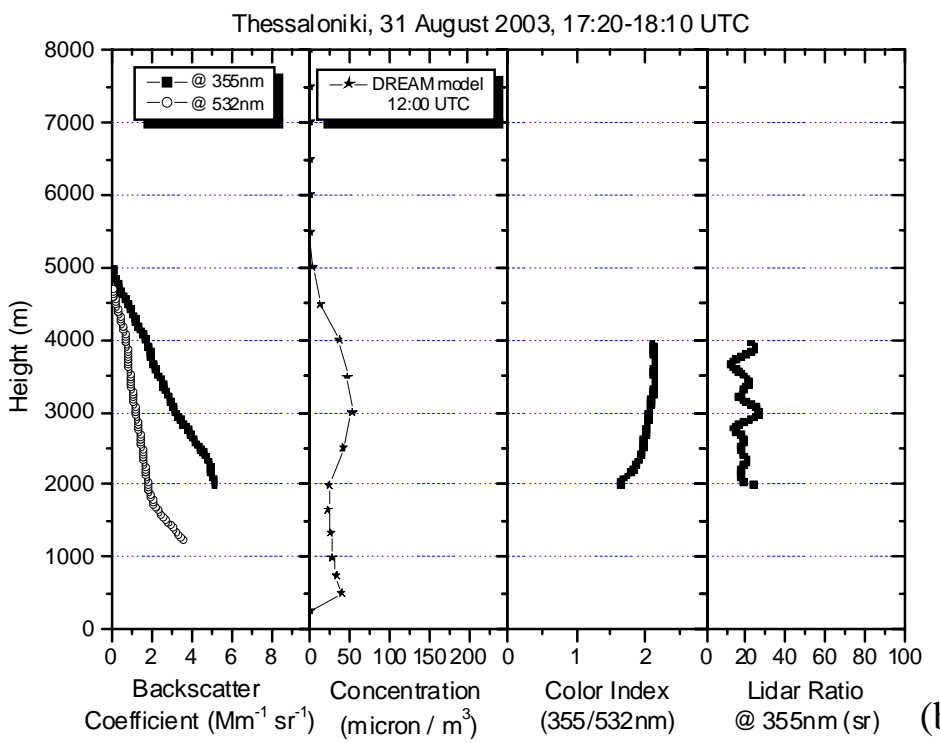

(b)

Fig. 7. Profiles of the aerosol backscatter coefficient at 532 and $355 \mathrm{~nm}$ (in $\mathrm{Mm}^{-1} \mathrm{sr}^{-1}$ ), the model (DREAM) estimated dust concentration (in $\mu \mathrm{g} / \mathrm{m}^{3}$ ), the color index and the lidar ratio (a) for 30 August 2003 and (b) for 31 August 2003 for Thessaloniki, Greece.

dust particles. Balis et al. (2004) also reported such cases where dust has been forecasted (and trajectory analysis confirmed the forecast), but the observed profiles showed values of the lidar ratio and color index which do not correspond to modeled values of mineral particles. This disagreement between the model forecast and the higher backscatter coefficients provides an indication that mineral dust has been well mixed with other types of aerosols, resulting in (a) higher aerosol loading and (b) a different lidar ratio. According to the observed small lidar ratio values, dust should have been mixed mostly with maritime aerosols and the dust contribu- tion to the overall aerosol loading should be small. Balis et al. (2004) have shown that over Thessaloniki mixing of dust with other aerosol types is common. This fact makes the separation of dust in the profiles difficult, or even impossible.

Figure 8 presents the vertical profiles of the aerosol backscatter coefficient measured over Finokalia in the evening of 30 August and in the morning of 31 August 2003, along with the profiles of the simulated dust concentration at 12:00 UTC for these two days. According to the model, on 30 August, there was no dust present over Finokalia and this is in agreement with the small backscatter values observed 


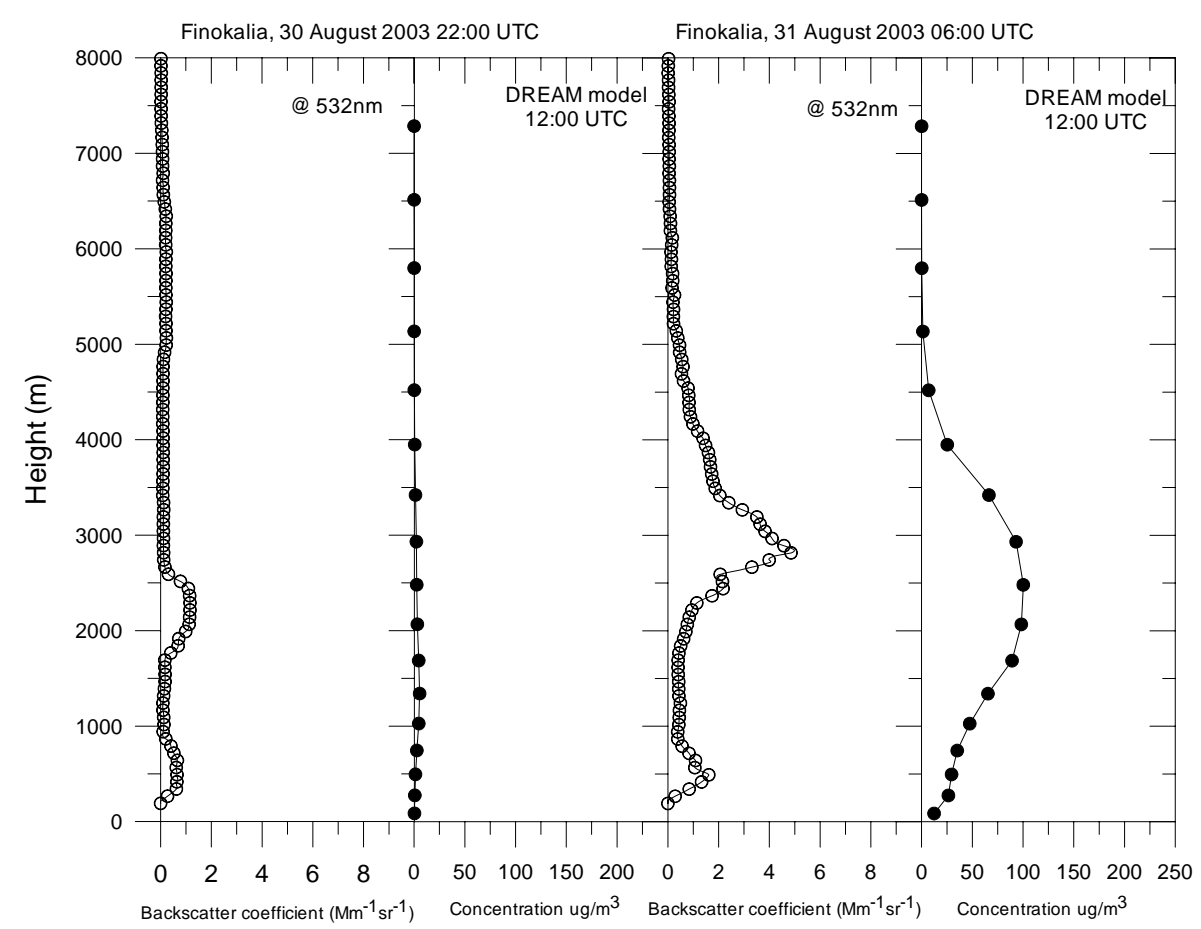

Fig. 8. Profiles of the aerosol backscatter coefficient at 532 (in $\mathrm{Mm}^{-1} \mathrm{sr}^{-1}$ ) and the model (DREAM) estimated dust concentration (in $\mu \mathrm{g} / \mathrm{m}^{3}$ ) for 30 August 2003 and 31 August 2003 for Finokalia, Greece.

during the early morning hours. On the contrary, on the 31 August the simulated dust concentration over Finokalia is half that the one calculated over Thessaloniki on $30 \mathrm{Au}$ gust, although the backscatter profiles observed at Finokalia at 06:00 UTC on 31 August are larger than the ones observed at Thessaloniki the day before. This also supports that mixing of dust and pollution aerosol took place over Finokalia in the morning hours of 31 August 2003.

Figure 9 presents the vertical profiles of the aerosol backscatter coefficients obtained over Athens at 355 and $532 \mathrm{~nm}$, profiles of the simulated dust concentration and profiles of the color index around 12:00 UTC on 30 and $31 \mathrm{Au}-$ gust, respectively. The aerosol backscatter coefficient ranges between 1 and $2.5 \mathrm{Mm}^{-1} \mathrm{sr}^{-1}$ values, quite close to the observations over Thessaloniki on the same day. The dust concentration profiles calculated by the DREAM model show much more dust over Athens on 31 August than on $30 \mathrm{Au}-$ gust, in agreement with the lidar observations. For both days the model reproduces the shape of the dust profiles in the free troposphere compared to the lidar measurements. On $30 \mathrm{Au}-$ gust the observed color index profile shows values ranging from 0.5 to 1.9 within the 1000 and $6000-\mathrm{m}$ height interval. The lowest color index values (less than 1) correspond well to the dust layer heights (at $2500 \mathrm{~m}$ and $4000-5000 \mathrm{~m}$ ) observed during that day over Athens. On 31 August when the dust event becomes more intense over Athens, the mean color index values range between 0.1 and 1 , confirming the intensification of the event for altitudes below $5500 \mathrm{~m}$. Color index values close to 1 are observed between 2000 and $4000 \mathrm{~m}$ and can be indicative of the presence of slightly smaller particles as a result of eventual mixing between dust and maritime/and or continental aerosols over Athens. Lidar ratio profile is available only for the night of 1 September. They range between 40 and $60 \mathrm{sr}$ inside the dust layer (between 4200 and $5200 \mathrm{~m}$ ) and are consistent with the mean value of $50 \mathrm{sr}$ observed over Thessaloniki two days before (Fig. 7).

\section{Summary and conclusions}

During the summer months high AOD values of 0.6 at $355 \mathrm{~nm}$ are systematically observed over the Eastern Mediterranean. These high values are mostly related to longrange transport of aerosols (desert dust, biomass burning, pollution) rather than local sources. The dust event presented highlights how the synergy of lidar, sunphotometer measurements, trajectory analysis and model calculations can improve our ability to determine the optical properties of Saharan dust in the area under highly complex aerosol conditions.

The spatial and temporal evolution of a Saharan dust outbreak during 30-31 August 2003 has been studied in detail using coordinated measurements by three lidar systems over Greece located at Thessaloniki, Athens and Finokalia, Crete. The circulation pattern captured is not common for the Mediterranean. 

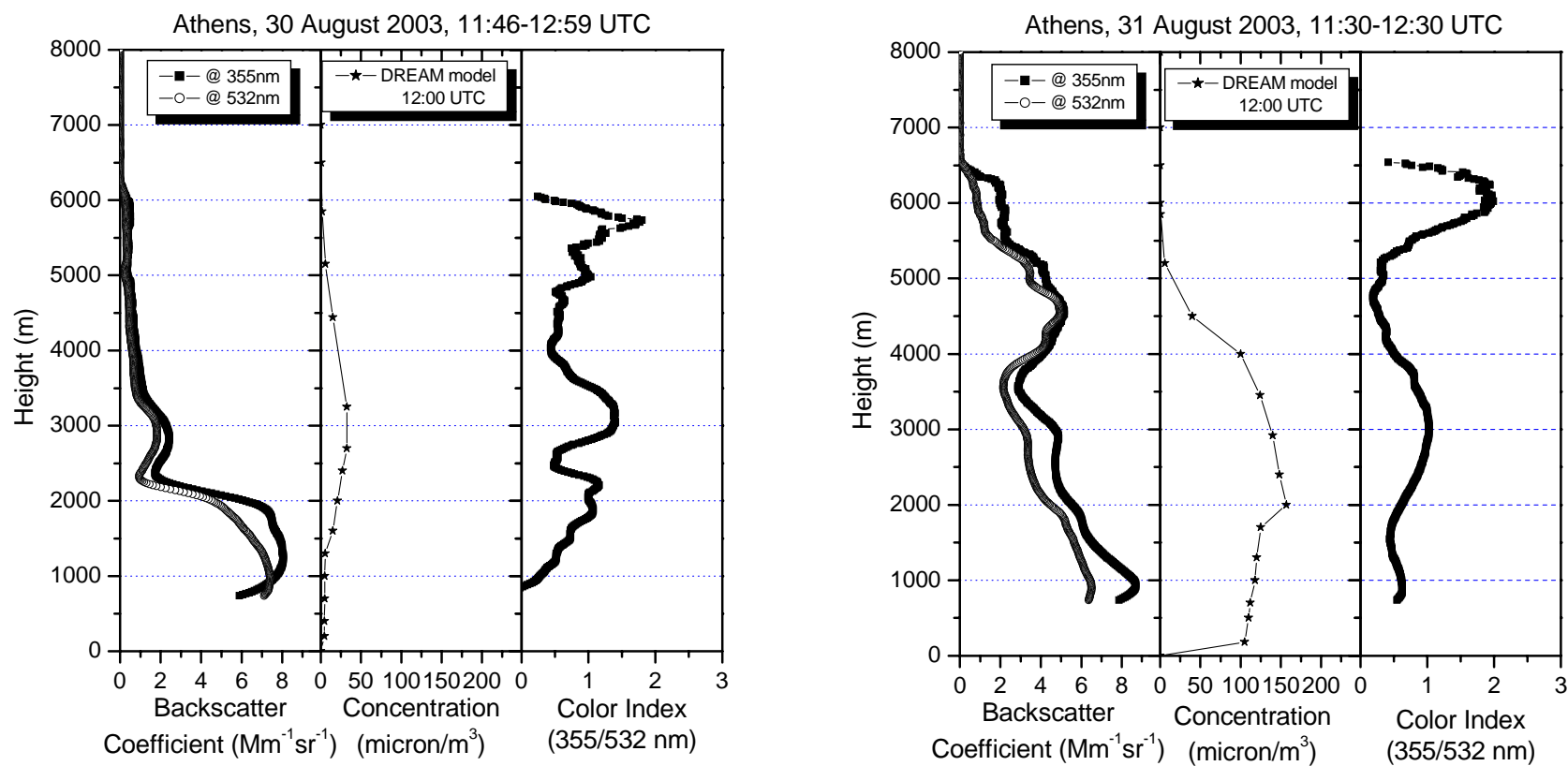

Fig. 9. Profiles of the aerosol backscatter coefficient at 532 and $355 \mathrm{~nm}$ (in $\mathrm{Mm}^{-1} \mathrm{sr}^{-1}$ ), the model (DREAM) estimated dust concentration (in $\mu \mathrm{g} / \mathrm{m}^{3}$ ) and the color index (left) for 30 August 2003 and (right) for 31 August 2003 for Athens, Greece.

Various aerosol layers originating from the Saharan dust region were observed over Greece with all three lidar systems until they finally collapsed and became mixed with aerosols from the PBL. Although the air masses over Athens had a different route and thus different spatial evolution than the ones reaching Thessaloniki and Finokalia, the dust particles originate from the same source located in the Western Saharan region.

The desert dust layer observed over Thessaloniki in the afternoon of 30 August 2003 arrived over Finokalia, Crete, some hours later and then faded into the PBL during the early morning hours of the next day. The differences in the observed backscatter coefficients between the two sites is due to the mixing with aerosol originating from Northern Greece and Turkey, since the model estimates for the dust concentration over Finokalia suggest smaller dust loading than the ones over Thessaloniki. Estimates of the dust load with the DREAM model and back-trajectory analysis with HYSPLIT confirm the discrete evolution of the events.

During the dust event over Thessaloniki the LR at $355 \mathrm{~nm}$ was found to be about $50 \mathrm{sr}$, representative for rather spherical mineral aerosols. During the fade out of the event, smaller LR values less than $20 \mathrm{sr}$ were found over Thessaloniki on 31 August and over Athens on 1 September, indicating that mineral dust should have been strongly diluted by mixing with maritime aerosols. Mixing of dust with aerosol from other sources commonly occurs over Greece and impedes the separation of dust in the aerosol profiles which are extremely case sensitive, showing that the case could imply large uncertainties if it is treated in a statistical way. Multi-wavelength lidar and sunphotometric measurements are thus essential for the calculation of the microphysical aerosol properties in the vertical, in order to increase our ability for the better characterization of the aerosol type.

Acknowledgements. This work was funded by the European Commission in the framework of PHOENICS (EVK2-CT-2001-00098) and EARLINET (EVR1-CT1999-40003) projects. Air mass back trajectories were calculated with the Hybrid Single-Particle Lagrangian Integrated Trajectory model (NOAA). S. Kazadzis acknowledges the support of IKY Foundation and V. Amiridis the support of the Greek Ministry of Education (Pythagoras EPEAEK-2 project). M. Vrekoussis, G. Tsaknakis, and S. Tzortzakis acknowledge the support of the GSRT (PENED and ENTER projects, respectively).

Topical Editor F. D'Andrea thanks two referees for their help in evaluating this paper.

\section{References}

Amiridis V., Balis, D., Kazadzis, S., Giannakaki, E., Papayannis, A., and Zerefos, C.: Four years aerosol observations with a Raman lidar at Thessaloniki, Greece, in the framework of European Aerosol Research Lidar Network (EARLINET), J. Geophys. Res., 110, D21203, doi:10.1029/2005JD006190, 2005.

Ansmann, A., Bösenberg, J., Chaikovsky, A., Comerón, A., Eckhardt, S., Eixmann, R., Freudenthaler, V., Ginoux, P., Komguem, L., Linné, H., Márquez, M. A. L., Matthias, V., Mattis, I., Mitev, V., Müller, D., Music, S., Nickovic, S., Pelon, J., Sauvage, L., Sobolewsky, P., Srivastava, M. K., Stohl, A., Torres, O., Vaughan, G., Wandinger, U., and Wiegner, M.: Long range transport of Saharan dust to northern Europe: The 11-16 October 
2001 outbreak observed with EARLINET, J. Geophys. Res., 108 (D24), 4783, doi:10.1029/2003JD003757, 2003.

Balis, D., Amiridis, V., Zerefos, C., Gerasopoulos, E., Andreae, M. O., Zanis, P., Kazantzidis, A., Kazadzis, S., and Papayannis, A.: Raman lidar and sunphotometric measurements of aerosol optical properties over Thessaloniki, Greece during a biomass burning episode, Atmos. Environ., 37, 4529-4538, 2003.

Balis, D., Amiridis, V., Nickovic, S., Papayannis, A., and Zerefos, C.: Optical properties of Saharan dust layers as detected by a Raman lidar at Thessaloniki, Greece, Geoph. Res. Lett., 31, doi:10.1029/2004GL019881, 2004.

Böckmann, C., Wandinger, U., Ansmann, A., Bösenberg, J., Amiridis, V., Boselli, A., Delaval, A., de Tomasi, F., Frioud, M., Grigorov, I. V., Hagard, A., Horvat, M., Iarlori, M., Komguem, L., Kreipl, S., Larcheveque, G., Matthias, V., Papayannis, A., Pappalardo, G., Rocadenbosch, F., Rodrigues, J. A., Schneider, J., Shcherbakov, V., and Wiegner, M.: Aerosol Lidar Intercomparison in the framework of the EARLINET project, 2. Aerosol backscatter algorithms, Appl. Opt., 43, 977-989, 2004.

Bösenberg, J., Balis, D., Flamant, P., Papalardo, G., Papayannis, A., Pelon, J., Schneider, J., Trickl, T., and Visconti, G.: EARLINET: A European Aerosol Research Lidar Network, in Advances in Laser Remote Sensing, Selected papers from the 20th International Laser Radar Conference, Vichy, France, 155-158, 2001.

Bösenberg, J.: EARLINET: A European Aerosol Research Lidar Network to establish an Aerosol Climatology, Final Report, MPIRep., Max-Planck-Inst. Für Meteorol., Hamburg, Germany, 348, 2003.

Carlson, T. N. and Caverly, R. S.: Radiative characteristics of Saharan dust at solar wavelengths, J. Geophys. Res., 82, 3141-3152, 1977.

Chourdakis, G., Georgoussis, G., Hondidiadis, K., and Ikonomou, A.: Monitoring Of Air Pollution Over An Urban Site Using A Mobile Backscatter Lidar System, Abstracts of the 5th International Conference on Urban Air Quality, Valencia, Spain, edited by: Sokhi, R., Milan, M., and Moussiopoulos, N., 81, 2005.

D'Almeida, G. A.: A model for Saharan dust transport, J. Clim. Appl. Meteorol., 24, 903-916, 1986.

Draxler, R. R. and Hess, G. D.: An Overview of the Hysplit_4 Modeling System for Trajectories, Dispersion, and Deposition, Aust. Met. Mag., 47, 295-308, 1998.

Hamonou, E., Chazette, P., Balis, D., Dulac, F., Schneider, X., Galani, E., Ancellet, G., and Papayannis, A.: Characterization of the vertical structure of Saharan dust export to the Mediterranean basin, J. Geophys. Res., 104, 22 275-22 270, 1999.

Holben, B. N., Eck, T. F., and Fraser, R. S.: Temporal and spatial variability of aerosol optical depth in the Sahel region in relation to vegetation remote sensing, Int. J. Remote Sens., 12(6), 11471163,1991

Holben, B. N., Eck, T. F., Slutsker, I., Tanre, D., Buis, J. P., Setzer, A., Vermote, E., Reagan, J. A., Kaufman, Y. J., Nakajima, T., Lavenu, F., Jankowiak, I., and Smirnov, A.: AERONET: A federated instrument network and data archive for aerosol characterization, Remote Sens. Environ., 66, 1-16, 1998.

Hoppel, W. A., Fitzgerald, W., Frick, G. M., Larson, R. E., and Mack, E. J.: Aerosol size distributions and optical properties found in the marine boundary layer over the Atlantic Ocean, J. Geophys. Res., 84, 3659-3686, 1990.
Houghton, J. T., Ding, Y., Griggs, D. J., Noguer, M., van der Linden, P. J., and Xiaosu, D.: Climate Change 2001: The Scientific Basis Contribution of Working Group I to the Third Assessment Report of the Intergovernmental Panel on Climate Change (IPCC), Cambridge University Press, 2001.

Husar, R. B., Prospero, J. M., and Stowe, L. L.: Characterization of tropospheric aerosols over the oceans with the NOAA advanced very high resolution radiometer optical thickness operational product, J. Geophys. Res., 102, 16 889-16910, doi:10.1029/96JD04009, 1997.

Israelevich, P., Ganor, E., Levin, Z., and Joseph, J.: Annual variations of physical properties of desert dust, J. Geophys. Res., 18, D13, 4381, doi:10.1029/2002JD003163, 2003.

Kazadzis, S., Bais, A., Kouremeti, N., Gerasopoulos, E., Garane, K., Blumthaler, M., Schallhart, B., and Cede, A.: Direct spectral measurements with a Brewer spectroradiometer: absolute calibration and aerosol optical depth retrieval, Appl. Opt., 44, 16811690, 2005.

Krüger, O. and Graß1, H.: The indirect aerosol effect over Europe, Geophys. Res. Lett., 29(19), 1925, doi:10.1029/2001GL014081, 2002.

Kubilay, N., Oguz, T., Kocak, M., and Torres, O.: Groundbased assessment of Total Ozone Mapping Spectrometer (TOMS) data for dust transport over the northeastern Mediterranean, Global Biogeochemical Cycles, 19, GB1012, doi:10.1029/2004GB002370, 2005.

Lelieveld, J., Berresheim, H., Borrmann, S., Curtzen, P. J., Dentener, F. J., Fischser, H., Feichter, J., Flatau, P. J., Hegland, J., Holzinger, R., Korrmann, R., Lawrence, M. G., Levin, Z., Karkowicz, K. M., Mihalopoulos, N., Minikin, A., Ramanathan, V., Reus, M. de, Roelofs, G. J., Scheeren, H. A., Sciare, J., Schlager, H., Schultz, M., Siegmund, P., Steil, B., Stephanou, E. G., Stier, P., Traub, M., Warneke, C., Williams, J., and Ziereis, H.: Global Air Pollution Crossroads over the Mediterranean, Science, 298, 794-799, 2002.

Marenco F., Santacesaria, V., Bais, A. F., Balis, D., di Sarra, A., Papayannis, A., and Zerefos, C.: Optical properties of tropospheric aerosols determined by lidar and spectrophotometric measurements Photochemical Activity and Solar Ultraviolet Radiation campaign, Appl. Opt., 36, 6875-6886, 1997.

Matthias, V., Freudenthaler, V., Amodeo, A., Balin, I., Balis, D., Bösenberg, J., Chaikovsky, A., Chourdakis, G., Comeron, A., Delaval, A., de Tomasi, F., Eixmann, R., Hagard, A., Komguem, L., Kreipl, S., Matthey, R., Rizi, V., Rodrigues, J. A., Wandinger, U., and Wang, X.: Aerosol Lidar Intercomparison in the framework of EARLINET project, 1. Instruments, Appl. Opt., 43, 961-976, 2004.

Mattis, I., Ansmann, A., Müller, D., Wandinger, U., and Althausen, D.: Dual-wavelength Raman lidar observations of the extinctionto-backscatter ratio of Saharan dust, Geophys. Res. Lett., 29, 1306, doi:10.1029/2002GL014721, 2002.

Mihalopoulos, N., Stephanou, E., Kanakidou, M., Pilitsidis, S., and Bousquet, P.: Tropospheric aerosol ionic composition in the eastern Mediterranean region, Tellus B, 49, 314-326, 1997.

Moulin, C., Dulac, F., Lambert, C. E., Chazette, P., Jankowiak, I., Chatenet, B., and Lavern, F.: Long-term daily monitoring of Saharan dust load over ocean using Meteosat ISCCP-B2 data, 2. Accuracy of the method and validation of Sun photometer measurements, J. Geophys., Res., 102, 16 959-16969, 1997. 
Müller, D., Mattis, I., Wandinger, U., Althausen, D., Ansmann, A., Dubovik, O., Eckhardt, S., and Stohl, A.: Saharan dust over a central European EARLINET-AERONET site: Combined observations with Raman lidar and Sun photometer, J. Geophys. Res., 108, 4345, doi:10.1029/2002/JD002918, 2003.

Murayama, T., Sugimoto, N., Uno, I., Kinoshita, K., Aoki, K., Hagiwara, N., Liu, Z., Matsui, I., Sakai, T., Shibata, T., Arao, K., Sohn, B.-J., Won, J.-G., Yoon, S.-C., Li, T., Zhou, J., Hu, H., Abo, M., Iokibe, K., Koga, R., Iwasaka, Y.: Ground-based network observation of Asian dust events of April 1998 in East Asia, J. Geophys. Res., 106, 18 345-13 360, 2001.

Nickovic, S., Kallos, G., Papadopoulos, A., and Kakaliagou, O.: A model for prediction of desert dust cycle in the atmosphere, J. Geophys. Res., 106, 18 113-18 130, 2001.

Papayannis, A., Balis, D., Amiridis, V., Chourdakis, G., Tsaknakis, G., Zerefos, C., Castanho, A., Nickovic, S., Kazadzis, S., and Grabowski, J.: Measurements of Saharan dust aerosols over the Eastern Mediterranean using elastic backscatter-Raman lidar, spectrophotometric and satellite observations in the frame of the EARLINET project, Atmos. Chem. Phys., 5, 2065-2079, 2005.

Pappalardo, G., Amodeo, A., Pandolfi, M., Wandinger, U., Ansmann, A., Bösenberg, J., Matthias, V., Amiridis, V., Tomasi, F. de, Frioud, M., Iarlori, M., Komguem, L., Papayannis, A., Rocadenbosch, F., and Wang, X.: Aerosol Lidar Intercomparison in the framework of the EARLINET project, 3. Raman lidar algorithm for aerosol extinction, backscatter and lidar ratio, Appl. Opt., 43, 5370-5385, 2004.

Penner, J. E., Charlson, R. J., Laulainen, N., Leifer, R., Novakov, T., Ogren, J., Radke, L. F., Schwartz, S. E., and Travis, L.: Quantifying and minimizing uncertainty of climate forcing by anthropogenic aerosols, Bull. Amer. Meteorol. Soc. 75, 375-400, 1994.
Prospero, J. M. and Carlson, T.: Saharan air outbreaks over the tropical North Atlantic, Pure Appl. Geophys., 119, 678-691, 1972.

Prospero, J. M., Savoie, D. L., Arimoto, R., and Huang, F.: Longterm trends in African mineral dust concentration over the western North Atlantic: Relationship to North African rainfall, EOS Trans., AGU, 74 (43), Fall Meet. Suppl., 146, 1993.

Prospero, J. M.: Saharan dust transport over the North Atlantic Ocean and Mediterranean: An overview, in: The Impact of Desert Dust Across the Mediterranean, edited by: Guerzoni, S. and Chester, R., Kluwer Acad., Norwell, Mass., 133-151, 1996.

Prospero, J. M.: Long-term measurements of the transport of African mineral dust to the Southeastern United States: Implications for regional air quality, J. Geophys. Res., 104, $15917-$ $15927,1999$.

Prospero, J., Ginoux, P., Torres, O., Nicholson, S., and Gill, T.: Environmental characterization of global sources of atmospheric soil dust identified with the Nimbus 7 Total Ozone Mapping Spectrometer (TOMS) Absorbing Aerosol product, Rev. Of Geophys., 40, 1, 2002.

Rodriguez, S., Querol, X., Alastey, A., Kallos, G., and Kakaliagou, O.: Saharan dust contributions to $\mathrm{PM}_{10}$ and TSP levels in southeastern and eastern Spain, Atmos. Environ., 35, 2433-2447, 2001.

Tomasi, C. and Prodi, F.: Measurements of atmospheric turbidity and vertical mass loading of particulate matter in marine environments (Red Sea, Indian Ocean, and Somalian coast), J. Geophys. Res., 87, 1279-1286, 1982.

Wafers, M. and Jaenicke, R.: Aerosols, Pergamon Press, N. York, 1990.

Zerefos, C., Ganev, K., Kourtidis, K., Tzortziou, M., Vasaras, A., and Syrakov, E.: On the origin of SO2 above Northern Greece, Geophys. Res. Lett., 27, 365-368, 2000. 